\title{
BIO-ECONOMIC APPROACH ON ASSESSING MANAGEMENT OPTIONS FOR THE FISHERY: The Case of Open Water Fishery of South Sumatra, Indonesia
}

\author{
Sonny Koeshendrajana") and Oscar Cacho")
}

\begin{abstract}
The issue of better management for tropical inland fisheries has become one of the major problems for Indonesia. For the decision-makers, the question of to whom to assign property rights is difficult because it involves an assessment of who can use the resource in the best interests of society. Practically, a major problem confronting management policies is how to determine the type and level of control which government should apply to fisheries in order to achieve the objectives of maintaining the flow of benefits derived from the fishery and improving the productivity of the resource on a sustainable basis. To deal with those issues, one possible approach is to formulate an appropriate management strategy for the resource through developing a model which can combine biological and economic aspects of the fishery. This approach has been widely defined as a bioeconomic approach. This paper discusses the potential of the model to measure the economic benefits of the fishery.

Surplus production models developed by Schaefer (1954) and Fox (1970) are used. The biological model for the inland fishery was begun with the assumption of zero rate of change in biomass all year and of an exact index of relative abundance. Economic models were developed by describing costs-returns of the fishery. Based on the incorporated biological and economic models, the current fishery management is evaluated and possible economic benefits are assessed. Further, a possible direction for better management option can be assessed.
\end{abstract}

KEYWORDS: bio-economic, assessing management, inland fishery, South Sumatra

\section{INTRODUCTION}

South Sumatra province of Indonesia has important rivers, such as the Musi, Ogan and Komering According to Kaida (1980), the hydrological condition of the province shows an extensive, swampy and constricted river basin. The temperature ranges from 21.5 to $32.7^{\circ} \mathrm{C}$. Rain falls throughout the year with the exception of a short dry period of 2-4 months. Rainfall averages $213 \mathrm{~mm}$ per month ( 1,500 to $3,200 \mathrm{~mm}$ per year). Humidity ranges from 82 to 91 per cent. Total population of the province was recorded at 6.66 million (BPS 1995), with a Gross Domestic Product (GDP) at current market prices rose from 3,438 billion Rupiah in 1983 to 11,050 billion Rupiah in 1993. During 1983-1993, the region achieved a continuous increase in GDP with the agricultural sector contributing 18.4 percent of total GDP in 1993, and fisheries sub sector contributing 2.0 per cent. However, the fishery is considered an important sector for the region because of its significant contribution as a source of income, employment and animal protein in the diet of many households, both in rural areas and urban centers. The contribution of fisheries to GDP remained relatively constant during the period 1988-1992. This may indicate that the continuing growing number of fishermen and fishing units entering the fisheries was not accompanied by increases in catch. In terms of property rights regimes, inland fishery resources may have assigned property rights. Some resources are managed by the community based on traditional fishing rights. However, problems similar to those of an open-access fishery commonly occur. Under such management, each individual can maximize his or her individual benefits from the resource. The tendency is for the fishers to deplete the resource. Consequently, the fishers faces falling and unevenly distributed income.

An open-access fishery will lead to over-fishing from both biological and economic points of view. Biological over-fishing occurs when the growth of the stock is lower than the rate of harvest. In this sense, growth and recruitment over-fishing were likely to happen. Economic over-fishing occurs because fishermen are attracted by expected high rates of return from harvesting the fish stock. This tends to continue to attract investment long after the rate of return from the fishery becomes negative (FAO, 1997). This phenomenon was clearly explained by Gordon (1954).

Researcher at the Research Institute for Freshwater Fisheries, Sukamandi
Senior Lecturer at the Department of Agricultural and Resource Economics, Australia 


\section{Characteristics of Inland Fisheries in South Sumatra}

The inland fishery in South Sumatra may be termed a typical 'floodplain fishery resource'. The resource is basically formed by the main river, and its major tributaries. The middle section of the rivers are characterised by extensive floodplains which are locally called 'lebak lebung'. 'The river levees, which are locally called 'talang', are only slightly higher than the surrounding terrain. The floodplain of the river is considered a more general feature of the river basin and includes the tributaries flowing into the main channel along the entire length of the river. Often the rivers cut through their own embankment, creating direct connections with the extensive floodplains. Some parts of the extensive floodplains are shallow depressions with no links or permanent drainage to the surrounding river systems and are fed by their own minor tributaries. The vegetation in the extensive floodplains is variable, such as forest (rawang), sedge and grasslands (lebak berkumpai).Some extensive floodplains, which are close to settlements, are used for rice production (sawah lebak).

The floodplain and the river system are controlled by hydrological cycles which can be classified as tropical floodplain rivers. During the rainy season, the river basins flood and water levels in the rivers are high, whereas during the dry season, the river basins drain and water levels in the rivers fall. Water bodies on the floodplain also lose water by evaporation and to a lesser degree by percolation during the dry season. In the cycle of the seasons, there are intermediate periods of rising and falling water levels. The nature of resource productivity is based primarily on energetic exchanges between terrestrial and aquatic cornponents of the ecosystem. Substantial energy in the resource system is derived from organic materials which are broken down by continuous interactive physical and biological processes and enter into the aquatic environment. These processes enrich primary productivity of the resource. Hence, floods in this type of ecosystem provide the stimulus and appropriate environment for spawning and early life history stages for the majority of fish species in tropical floodplain fisheries.

Fishing is traditionally considered an important occupation for many rural people living in the area. Fishing patterns in the area are significantly affected by fluctuations in water levels. The fishing seasons can be distinguished as high water (December to February), receding water (March to May), low water (June to August) and rising water (September to November). The types of fishing gear operated depend on both area and season.

\section{Production system of the fishery}

Most floodplain river fisheries experience increased fishing during periods of low flow with the greatest catch per unit of effort (CPUE) often associated with falling or rising water levels (Jackson, 1989; Malvestuto, 1989). Fish are more concentrated in low water and tend to become migrationally active during rising and falling water. Hence, they are more susceptible to capture during these times. In this regard, the structure and functional composition, as well as abundance of fish stocks, are reflected in the types and intensities of fishing effort operated during this time of the year. Fish stock typically recover from intense low water exploitation during the high water season, when fishing efficiency is low due to dispersion of fish in newly inundated areas.

Although Jackson (1989) and Malvestuto (1989) considered South Sumatra to have basically a floodplain river fishery, they observed that the province had various types of inland fishery resources. However, official records (Fisheries Services of South Sumatra, various years) classify the inland fishery into only three types of resources, namely: rivers, swamps and lakes. Many different types of fishing units are used by fishermen; however, the Fisheries Service of South Sumatra divides those units into 10 categories.

Almost all fishing units in the tropical floodplain fishery are artisanal, small-scale and labour-intensive. Many of the fishing units can be operated only for a short time, given water levels appropriate to use of particular gear. Consequently, fishermen tend to operate a succession of fishing units as water levels change.

The composition of the fish stock may vary both spatially according to types of resource and temporally due to variation in spawning success (Gulland and Garcia, 1984). Each species of the fish stock specialises to take advantage of a limited range of foods but is also able to switch its feeding preference as the season progresses to take advantage of food sources which become abundant for limited times. This indicates that many species of fish respond to the diversity of available foods. In terms of growth, the fish stock may be characterised as fast-growing and seasonal. Many large species grow particularly fast in their first season. This is possibly an adaptation to avoid intense predation on the floodplain by rapidly exceeding edible size before the shelter of the floating vegetation disappears in the dry season. Alternatively, they may remain vulnerable to predators all their lives but mature and breed as early as possible. Given the above, the effect of mortality due to fishing on such aggregated variable fish stock is very complicated and difficult to gauge. This is because the fish- 
ery is very complex, comprising many different fishing units, multi-species with different harvested sizes, seasonal factors and variation between fishing grounds

Over one hundred species of fish are currently being harvested from the fishery. However, officia records of the Fisheries Service combine all harvested fish into only 17 species. In contrast, Welcomme (1985) classified floodplain fish species into two broad categories, i.e., whitefish and blackfish. According to this classification, whitefish can be distinguished by their behaviour in terms of the pattern of migration. They migrate spatially and seasonally, from the river to the floodplain area every year to obtain nutritious foods and must return to the river due to intolerance of low oxygen in the dry season. Blackfish, on the other hand, may spend their whole lives in the standing waters of the floodplain. These migratory patterns may divide the community of tropical floodplain fish stock by different habitats. Knowledge of fish migratory pattern indicates to fishers where and when most fish can be captured. Unfortunately, recorded data on such fish species groups are not available for the study site. This, in turn, creates difficulties in modeling the biology of the fishery according to particular species.

It is obvious that fisheries management entails a complex and wide-embracing set of tasks, aimed at ensuring that the optimal benefits are obtained for the local users, stakeholders who are involved in the fishery. However, in this context, this paper introduces one possible method of assessing management options for the inland fishery resource using a bioeconomic approach.

\section{METHODOLOGY}

The inland capture fishery system in South Sumatra, Indonesia, may be simplified into four submodels, i.e., biological submodel, (social) economic submodel, bioeconomic submodel and management submodel. The biological submodel describes the population dynamics of the fisheries. The economic submodel describes the prices, revenues and costs from harvesting the fish stock using a composite production factor called fishing effort. The bioeconomic submodel describes the combination of biological and economic models applied to the fishery. The management submodel describes the policies and regulations which might be imposed by the manager

\section{Models for Assessing Management Options}

Surplus production models of Schaefer (1954) and Fox (1970) are used in this study which simply written respectively as:
(1) $\frac{d X}{d t}=r X-\frac{r}{K} X^{2}-q X E$

(2) $\frac{\mathrm{dX}}{\mathrm{dt}}=\mathrm{rX} \ln \left(\frac{\mathrm{K}}{\mathrm{X}}\right)-\mathrm{qXE}$

where $\mathrm{K}$ is carrying capacity, a parameter corresponding to the unfished equilibrium stock size, $r$ is intrinsic growth rate of the fish, $X$ is fish stock, $E$ is fishing effort and $q$ is catchability coefficient. The continuous form of the Schaefer model in equation (1) assumes that the growth rate to fish stock relationship is logistic. The Fox model on the other hand, assumes a 'Gompertz growth' fish stock relationship (Yoshimoto and Clarke, 1993). This model exhibits an asymmetrical stock production curve. The model, in turn, describes an exponential relationship between fishing effort and stock size. Those are similar in the sense that they show a decline in catch per unit of effort (CPUE) with increasing fishing effort. Both stock production curves imply that at a lower level of effort, each additional unit of fishing effort will add a positive increment to the sustainable catch. However, additional catch declines as fishing effort increases further. Beyond the maximum point of the sustainable yield curve, an additional unit of fishing effort will decrease the sustainable catch. The two models differ in terms of their definition of the relationship between catch per unit effort and fishing effort. The former model assumes a declining linear relationship whereas the latter assumes a declining logarithmic relationship as shown respectively in the following equations:

(3) $\frac{Y}{E}=a-b E$

(4) $\operatorname{Ln}\left(\frac{Y}{E}\right)=a-b E$

Following the Gordon (1954) formulation, total cost and total revenue of the fishery are expressed in terms of fishing effort. If fishing effort has no effect on factor price, cost per unit of fishing effort is constant. Hence, the relationship between total cost and fishing effort would be linear. This means that the average and marginal costs of fishing effort are the same. The total cost of fishing (TC), marginal cost (MC) and average cost $(A C)$ can be written as

(5) $\mathrm{TC}=\mathrm{cE}$

(6) $\mathrm{AC}=\mathrm{MC}=\mathrm{c}$

where $c$ is cost per unit of fishing effort. Then, total revenue (TR), marginal revenue (MR) and average revenue (AR) functions are:

(7) $\mathrm{TR}=\mathrm{pY}=\mathrm{p}\left(\mathrm{aE}-\mathrm{bE}^{2}\right)$

(8) $M R=p(a-2 b E)$ 
(9) $A R=p(a-b E)$

where $p$ is price of fish, a equals $q K, b$ equals $\left(q^{2} K\right) / r$. This model can be used to find the level of effort which results in MSY and maximum economic yield (MEY) in the long run.

\section{RESULTS AND DISCUSSIONS}

The data used in this syudy were abtained from the fisheries service of South Sumatera (Appendix 1a) and across-sectoral survey in 1999. Using the data in Appendix 1, the calculated effort, catch, cost, revenue and profit derived from the inland fishery in South Sumatra are presented in Table 1. It should be noted that the level of effort which maximises social benefit is represented by the MEY condition which sets price equal to marginal cost. An unregulated fishery is represented by the 'bionomic' condition which sets average revenue equal to average cost

These figures imply that the average level of effort should be reduced by 34 per cent in order to reach MEY and by 6 per cent to reach the MSY; however, the calculated catch will increase by 10 per cent and 21 per cent, respectively. It should be noted that a such great reduction in effort may require a reduction in the number of fishers and create unemployment. Since the current situation indicates over-fishing, the authorities should impose regulations to maintain sustainability of the resource.

The biological parameters in terms of catchability coefficient $(q)$, intrinsic growth rate $(r)$ and carrying capacity $(K)$ in the resources can be estimated. This, in turn, considers a 'base case' representing the existing situation for the inland fishery (Appendix 2). With this, policy options can be incorporated into the 'base model'.

\section{SUMMARY AND CONCLUDING REMARKS}

In summary, the main policy implication derived from the study was that proper regulation of the inland fishery in South Sumatra would require control of the total standardised fishing effort. Results indicate that the fishery has been over-fished. Therefore, to achieve the purpose of an economically efficient management policy, the level of fishing effort should be reduced. That would result in a reduction in average cost per unit of effort. However, reducing fishing effort indiscriminately is not desirable; the reduction in fishing effort should be accompanied by creation of alternative productive activities

Based on the Gordon-Schaefer approach (Panayotou, 1982), the opportunity cost of fishing was included in the bioeconomic model, hence the objective of fishery management was to maximise social yield. Given this revised objective, the reduction in average fishing effort required to achieve optimum resource allocation was less than in the standard bioeconomic model.

With very limited data as shown, many interesting aspects of the fishery were left unexplored. However, the surplus production model was the best option avail-

Table 1. Calculated effort, catch, costs, revenues and profits of the inland fishery in South Sumatra, Indonesia, based on the Copes model ${ }^{1)}$ (Copes, 1970)

\begin{tabular}{lccccc}
\hline $\begin{array}{c}\text { Critical } \\
\text { condition }\end{array}$ & $\begin{array}{c}\text { Effort } \\
\text { (trips) }\end{array}$ & $\begin{array}{c}\text { Catch } \\
\text { (tonnes) }\end{array}$ & $\begin{array}{c}\text { Cost } \\
\text { (million rp) }\end{array}$ & $\begin{array}{c}\text { Revenue } \\
\text { (million rp) }\end{array}$ & $\begin{array}{c}\text { Profit } \\
\text { (million rp) }\end{array}$ \\
\hline Rivers: & & & & & \\
MSY & $6,606,547$ & 27,467 & 19,645 & 33,372 & 13,727 \\
MEY & $4,662,019$ & 25,087 & 13,863 & 30,481 & 16,618 \\
MSCY & $5,315,956$ & 26,419 & 13,038 & 32,099 & 19,060 \\
BE & $9,324,038$ & 22,819 & 27,726 & 27,726 & 0 \\
BES & $10,631,913$ & 17,270 & 20,983 & 20,983 & 0 \\
Actual (average) & $7,009,797$ & 22,775 & 20,844 & 27,671 & 6,827 \\
Swamps: & & & & & \\
MSY & $5,052,362$ & 17,342 & 13,295 & 19,509 & 6,214 \\
MEY & $3,091,839$ & 16,470 & 8,136 & 18,529 & 10,393 \\
MScY & $3,551,736$ & 17,342 & 5,795 & 19,509 & 13,715 \\
BE & $6,183,678$ & 14,464 & 16,272 & 16,272 & 0 \\
BES & $7,103,472$ & 10,301 & 11,589 & 11,589 & 0 \\
Actual (average) & $5,414,912$ & 14,830 & 14,249 & 16,684 & 2,435 \\
\hline
\end{tabular}

Note:

1) Calculated from the Schaefer model (Schaefer, 1954;Gordon, 1954) 
able to obtain estimates of biological parameters. The lack of time series data on many social, economic and cultural variables resulted in simplification of the dynamics of the fishery system.

\section{REFERENCES}

BPS (Biro Pusat Statistik, Center Bureau of Statistics). 1995, Sumatra Selatan dalam Angka (South Sumatra in figures) 1994, BPS, Jakarta.

Copes, P. 1970. The backward-bending supply curve of the fishing industry, Scottish Journal of Political Economy 17: 69-77.

FAO. 1997. Fisheries Management, FAO Technical Guidelines for Responsible Fisheries, no. 4, FAO, Rome. $82 \mathrm{pp}$.

Fisheries Service of South Sumatra. Various years, Annual fisheries statistics, Fisheries Service of South Sumatra, Indonesia.

Fox, W.W. 1970. An exponential surplus-yield model for optimising exploited fish populations, Trans. Amer. Fish. Soc., 1: 80-88.

Gordon, H.S. 1954. The economic theory of a common property resource : the fishery, J. Pol. Econ. 62, 12442.

Gulland, J.A. and S. Garcia. 1984. Observed patterns in multispecies fisheries, In Exploitation of marine communities, ed. May, R.M., Springer-Verlag, p : 155-190.
Jackson, D.C. 1989, Research orientations for developing management strategies for the Musi River Fishery, Fisheries Research and Development Project (FRDP) Report. Pusat Penelitian dan Pengembangan Perikanan, Jakarta.

Kaida, Y. 1980. Physiographic regions in the Komering Ogan river basin, South Sumatra, In South Sumatra Man and Agriculture, eds. Tsubouchi, Y. et al., The Center for Southeast Asian Studies, Kyoto University, Kyoto, Part II (2).

Malvestuto, S.P. 1989. Project proposal considerations for the Musi River fishery in South Sumatra, Indonesia, Fisheries Research and Development Project (FRDP) Report. Pusat Penelitian dan Pengembangan Perikanan, Jakarta.

Panayotou, T. 1982. Management Concepts for SmallScale Fisheries : Economic and Social Aspects, FAO Fisheries Technical Paper No. 228.

Schaefer, M.B. 1954. Some aspect of the dynamics of population important to the management of the commercial marine fisheries, Bulletin of the Inter American Tropical Tuna Commission 1 (2): 27-56.

Welcomme, R.L. 1985. River fisheries, FAO Fisheries Technical Paper, 262, 330 p6.

Yoshimoto, S.S., and R.P. Clarke. 1993. Comparing dynamic versions of the Schaefer and Fox production models and their application to lobster fisheries, Can. J. Fish. Aquat Sci. 50: 181-189. 
Appendix 1a. Average calculated catch, standard fishing effort, and catch per unit effort of inland fishery in South Sumatra, Indonesia, 1979-1994

\begin{tabular}{|c|c|c|c|c|c|c|}
\hline \multirow[b]{2}{*}{ Year } & \multicolumn{3}{|c|}{ Riverine } & \multicolumn{3}{|c|}{ Swamp } \\
\hline & $\begin{array}{l}\text { Catch } \\
\text { (ton) }\end{array}$ & $\begin{array}{c}\text { Effort }^{1} \\
\text { (trip) }\end{array}$ & $\begin{array}{l}\text { CPUE } \\
\text { (kg/trip) }\end{array}$ & $\begin{array}{l}\text { Catch } \\
\text { (ton) }\end{array}$ & $\begin{array}{c}\text { Effort }^{1} \\
\text { (trip) }\end{array}$ & $\begin{array}{l}\text { CPUE } \\
\text { (kg/trip) }\end{array}$ \\
\hline 1979 & $19,226.90$ & $7,968,722$ & 2.41 & $8,886.80$ & $4,640,975$ & 1.91 \\
\hline 1980 & $20,245.20$ & $9,767,450$ & 2.07 & $11,793.50$ & $4,787,623$ & 2.46 \\
\hline 1981 & $24,934.50$ & $12,848,280$ & 1.94 & $12,380.80$ & $7,573,612$ & 1.63 \\
\hline 1982 & $22,800.90$ & $10,658,653$ & 2.14 & $13,185.70$ & $6,597,145$ & 2 \\
\hline 1983 & $22,753.10$ & $9,180,946$ & 2.48 & $13,581.90$ & $6,842,005$ & 1.99 \\
\hline 1984 & $22,691.50$ & $8,364,851$ & 2.71 & $13,515.30$ & $6,731,566$ & 2.01 \\
\hline 1985 & $23,344.60$ & $7,057,137$ & 3.31 & $15,074.50$ & $4,557,570$ & 3.31 \\
\hline 1986 & $23,922.20$ & $5,933,176$ & 4.03 & $15,983.60$ & $4,802,313$ & 3.33 \\
\hline 1987 & $24,180.40$ & $4,878,222$ & 4.96 & $16,429.60$ & $5,858,133$ & 2.8 \\
\hline 1988 & $24,489.90$ & $4,988,222$ & 4.91 & $15,606.20$ & $6,830,128$ & 2.28 \\
\hline 1989 & $23,896.20$ & $5,233,669$ & 4.57 & $14,764.90$ & $4,785,324$ & 3.09 \\
\hline 1990 & $22,832.80$ & $8,753,780$ & 2.61 & $15,127.40$ & $5,735,803$ & 2.64 \\
\hline 1991 & $23,186.70$ & $5,804,116$ & 3.99 & $16,489.10$ & $4,926,004$ & 3.35 \\
\hline 1992 & $21,569.00$ & $4,082,591$ & 5.28 & $18,094.10$ & $2,993,435$ & 6.04 \\
\hline 1993 & $22,072.00$ & $2,618,949$ & 8.43 & $19,409.70$ & $2,153,145$ & 9.01 \\
\hline 1994 & $22,248.80$ & $4,017,995$ & 5.54 & $19,730.40$ & $3,348,192$ & 5.89 \\
\hline Average & $22,774.67$ & $7,009,797$ & 3.84 & $15,003.34$ & $5,197,686$ & 3.36 \\
\hline
\end{tabular}

Source : Based on data from Fisheries Service of South Sumatra (various years)

Note:

1) Effort is a standard fishing effort in terms of bamboo fishing trap (bubu)

2) Swamp data consists of swamp and lake fishery data 
Appendix 1b. Calculated costs of fishing effort by bamboo fishing traps (bubu) in different types of resources in South Sumatra

\begin{tabular}{lcc}
\hline \multirow{2}{*}{ Type of costs } & \multicolumn{2}{c}{ Type of resource } \\
\cline { 2 - 3 } & $\begin{array}{c}\text { Riverine } \\
\text { (rupiah) }\end{array}$ & $\begin{array}{c}\text { Swamp } \\
\text { (rupiah) }\end{array}$ \\
\hline Fixed Costs & 26.2 & 103.71 \\
Depreciation of canoe/boat & -0.88 & -3.94 \\
& 1184.21 & 936 \\
Depreciation of gear & -39.82 & -35.57 \\
& 131.58 & 266.67 \\
Lease of resource & -4.42 & -10.13 \\
& & \\
Variable Costs & 631.58 & 325 \\
Operating costs (bait and food) & -21.24 & -12.35 \\
& 1000 & 1000 \\
Labour & -33.64 & -38.01 \\
Total costs & 2973.57 & 2631.48 \\
& -100 & -100 \\
\hline
\end{tabular}

Source : Cross-sectional survey 1994

Remark: Values in the parentheses are percentage figure 
Appendix 2. Description and values of model parameters and variables based on Copes model ${ }^{2}$

\begin{tabular}{clll}
\hline \multirow{2}{*}{ Parameter } & \multicolumn{2}{c}{ Definition } & \multicolumn{2}{c}{ Base } & \multicolumn{1}{c}{ Value } \\
\cline { 3 - 4 } & & \multicolumn{1}{c}{ Riverine } & \multicolumn{1}{c}{ Swamp } \\
\hline$r_{i}$ & Intrinsic growth rate & 1.397 & 2.861 \\
$q_{i}$ & Catchability coefficient & $1.058\left(10^{-7}\right)$ & $3.325\left(10^{-7}\right)$ \\
$K_{i}$ & Carrying capacity & $78,621,512$ & $25,007,179$ \\
$X_{i}$ & Stock size $(\mathrm{kg})$ & $23,141,131$ & $7,034,846$ \\
$E_{i}$ & Effort (day trip) & $9,324,472$ & $6,183,575$ \\
$Y_{i}$ & Catch (kg) & $22,820,553$ & $14,463,960$ \\
$\mathrm{p}_{i}$ & Price of fish (Rp) & 1,215 & 1,125 \\
$\mathrm{C}_{i}$ & Cost of fishing effort (Rp) & $2,973.57$ & $2,631.48$ \\
\hline
\end{tabular}

Note:

$i$ : The type of resources, i.e., $i=1$ (riverine) and $i=2$ (swamp)

a) The Copes model is derived from estimates of the Schaefer model 